\title{
Synthesis, X-Ray Powder Diffraction Studies and Antimicrobial Activities of Novel Shiff Base Derivatives
}

\author{
V. M. BAROT ${ }^{1}$, S. A. GANDHI ${ }^{2}$, U. H. PATEL ${ }^{3}$ and M. C. PATEL ${ }^{1}$ \\ ${ }^{1}$ P. G. Center in Chemistry, Smt. S. M. Panchal Science College, \\ Talod, Gujarat 383 215, India \\ ${ }^{2}$ Shree P. M. Patel College of Electronics and Communications, \\ Anand, Gujarat 388 001, India \\ ${ }^{3}$ Department of Physics, Sardar Patel University, Vallabh Vidyanagar, Gujarat 388120, India \\ sahajg7@gmail.com
}

Received 18 January 2015 / Accepted 13 February 2015

\begin{abstract}
Schiff bases are an important class of organic compounds, which play and an important role in medicinal and pharmaceutical applications. The synthesized compounds, 1-(4-butoxy-2hydroxyphenyl) ethylidene- benzohydrazide (I), 1-(4-butoxy-2-hydroxy phenyl) ethylidene-4-chloro benzohydrazide (II) and 1-(4-butoxy-2-hydroxy phenyl) ethylidene-4-methyl benzohydrazide (III) have been characterized by FTIR, ${ }^{1} \mathrm{H}$ and ${ }^{13} \mathrm{C}$ NMR. The structural characterizations of synthesized compounds (I, II and III) have been estimated by analyzing powder X-ray diffraction technique. It is observed that samples I and III have crystallized in triclinic system with P $\overline{1}$ space group and sample II in monoclinic system with $\mathrm{P} 2{ }_{1} / \mathrm{n}$ space group. The synthesized compounds have been screened for its antimicrobial and antifungal activities against different panel of organisms.
\end{abstract}

Keywords: Schiff base, Powder x-ray diffraction, Antimicrobial, Antifungal activities

\section{Introduction}

Schiff bases are condensation products of primary amines and carbonyl compounds and they discovered by a German chemist, Nobel Prize winner, Hugo Schiff in 1864. Structurally, Schiff base (also known as imine or azomethine) is an analogue of a ketone or aldehyde in which the carbonyl group $(\mathrm{C}=\mathrm{O})$ has been replaced by an imine or azomethine group. Schiff base ligands are essential in the field of coordination chemistry, especially in the development of complexes of Schiff bases because these compounds are potentially capable of forming stable complexes with metal ions ${ }^{1}$. The individual Schiff bases are considered to be promising antifungal medicines ${ }^{2}$. Isatin Schiff base ligands are marked by antiviral activity, and this fact is very useful in the treatment of $\mathrm{HIV}^{3}$. In addition, it is also found that these compounds have anticonvulsant activity and may be included in the anti-epileptic drugs $^{4}$. Due to the presence of the imine group, the electron cloud of the aromatic ring and electronegative nitrogen, oxygen and sulfur atoms in the Schiff bases molecules, these compounds effectively prevent corrosion of mild steel, copper, aluminum and zinc in acidic 
medium ${ }^{5}$. Schiff bases and Mannich bases of isatin are known to possess a wide range of pharmacological properties including antibacterial, anticonvulsant, antifungal and antiviral activities $^{6-9}$. Schiff's bases are also important compounds owing to their wide range of industrial applications ${ }^{10}$. As a part of our ongoing research on syntheses of novel bio-organic molecules and their biological studies ${ }^{11-13}$, here we report the synthesis of 1-(2-hydroxy-4butoxyphenyl) ethanone with benzohydrazide, chloro-benzohydrazide and methylbenzohydrzide using schiff base method, with the characterizations by IR, ${ }^{1} \mathrm{H}$ and ${ }^{13} \mathrm{C}$ NMR. We also included powder X-ray diffraction study to investigate crystallographic information of the compound to find out the exact position of the different substituents. To understand pharmacological applications on structural basis, we evaluated antimicrobial and antifungal activities of the synthesized products against different panel of organisms.

A large number of different synthetic methods for the preparation of schiff base have been described in the literature ${ }^{14-15}$, so considerable attention has been given to the development and synthesis of schiff base for obtaining better biological potent molecules, which have been prepared by the reaction of ketone and different substituted hydrazide in dry benzene. A schiff base has nitrogen analog of an aldehyde or ketone in which the $\mathrm{C}=\mathrm{O}$ group is replaced by a $\mathrm{C}=\mathrm{N}-\mathrm{R}$ group. It is usually formed by condensation of an aldehyde or ketone with a primary amine.

\section{Experimental}

All chemicals and regents were commercially available from Sigma Aldrich, Merck and were used without further purification. Glassware was oven dried for several hours. General Melting points were determined on an electro thermal melting point apparatus. Completion of reaction and purity of all compounds were checked on aluminum coated TLC plates 60 F245 (E. Merck) using $n$-hexane: ethyl acetate $(7.5: 2.5, \mathrm{v} / \mathrm{v})$ as mobile phase and visualized under ultraviolet (UV) light, or iodine vapor. Elemental analysis $(\% \mathrm{C}, \mathrm{H}, \mathrm{N})$ was carried out by a Perkin-Elmer 2400 CHN analyzer. IR spectra of all the compounds were recorded on a Perkin-Elmer FT-IR spectrophotometer in $\mathrm{KBr} .{ }^{1} \mathrm{H}$ NMR spectra were recorded on a Varian Gemini $300 \mathrm{MHz}$ and ${ }^{13} \mathrm{C}$ NMR spectra on a Varian Mercury-400 (100 MHz) in DMSO-d6 as a solvent and tetramethylsilane (TMS) as an internal standard. Chemical shifts were reported in parts per million (ppm). Mass spectrum was scanned on a Shimadzu LCMS 2010 spectrophotometer.

\section{Synthesis}

Preparation of 1-(4-butoxy-2-hydroxyphenyl) ethylidene-benzohydrazide (I)

1-(2-Hydroxy-4-butoxyphenyl) ethanone $(0.208 \mathrm{~g}, 0.01 \mathrm{~mole})$ and benzohydrazide $(0.150 \mathrm{~g}$, 0.01 mole) were dissolved in dry benzene $(50 \mathrm{~mL})$. The solution was refluxed for $20-24 \mathrm{~h}$. Completion of reaction was checked by TLC and benzene was distilled out under pressure. The crude mass was poured in water. The resulting solid was filtered and washed with petroleum ether. The final product was crystallized from ethanol as dark yellow needles.

\section{1-(4-Butoxy-2-hydroxyphenyl)ethylidene-4-chlorobenzohydrazide (II)}

1-(2-Hydroxy-4-butoxyphenyl) ethanone $(0.01$ mole $)$ and 4-chlorobenzohydrazide $(0.01 \mathrm{~mole})$ were dissolved in dry benzene $(50 \mathrm{~mL})$. The solution was refluxed gently for 20-24 h using refluxed apparatus and water has been removed. The completion of reaction was checked by TLC and benzene was distilled out under pressure. The crude mass was poured in water. The resulting solid obtained was filtered and washed with petroleum ether. The final product was crystallized from ethanol as dark yellow needles. 


\section{1-(4-Butoxy-2-hydroxyphenyl) ethylidene-4-methylbenzohydrazide (III)}

1-(2-Hydroxy-4-butoxyphenyl) ethanone ( $0.208 \mathrm{~g}, 0.01 \mathrm{~mole})$ and 4-methylbenzohydrazide $(0.150 \mathrm{~g}, 0.01 \mathrm{~mole})$ were dissolved in dry benzene $(50 \mathrm{~mL})$. The solution was refluxed for 20-24 h and water has been removed. The completion of reaction was checked by TLC and benzene was distilled out under pressure. The crude mass was poured in water. The resulting solid obtained was filtered and washed with petroleum ether. The final product was crystallized from ethanol as dark yellow needles.<smiles>C=C(N/N=C(\C)c1ccc(OCCCC)cc1O)c1ccccc1</smiles>

Benzohydrazide 1-(4-Butoxy-2-hydroxyphenyl) ethylidene-benzohydrazide (I)

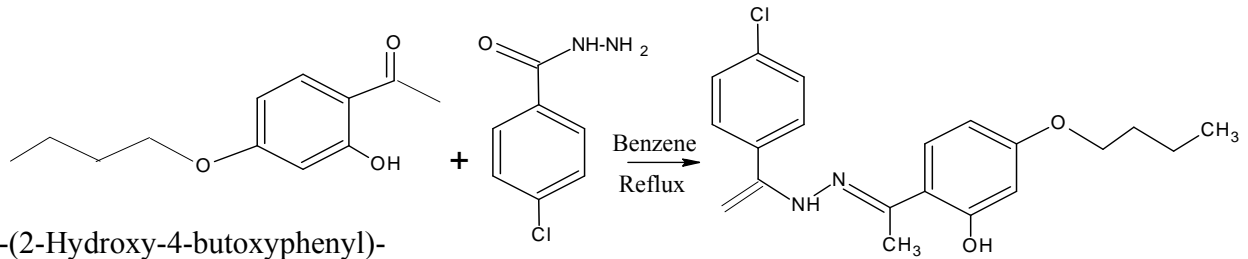
ethanone 4-Chlorobenzohydrazide 1-(4-Butoxy-2-hydroxyphenyl)ethylidene-

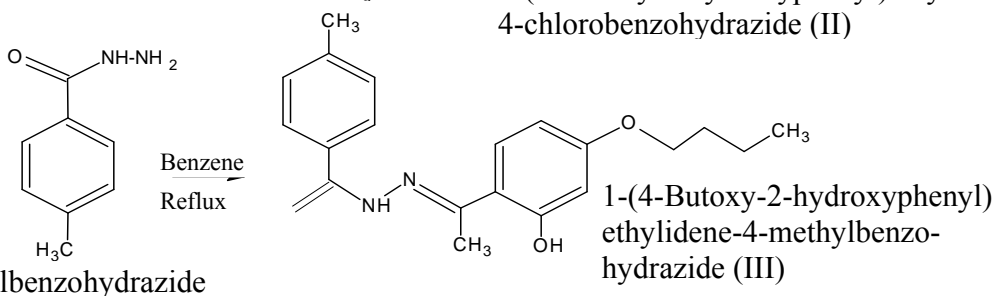

4-Methylbenzohydrazide

Figure 1. Reaction scheme of the synthesized compounds (I, II and III)

\section{Characterization of compounds}

\section{1-(4-Butoxy-2-hydroxyphenyl) ethylidene-benzohydrazide (I)}

IR $\left(\mathrm{cm}^{-1}\right): 3268(\mathrm{Ar}-\mathrm{OH}$, Phenol),1178(C-O, Phenol), 1274 [C-O-C, (sym) Ether], 1110 [CO-C (asym,) Ether], 1660 (C=O str. Schiff base),1559, ( $\mathrm{N}=\mathrm{C}$ str. Schiff base), 3210(N-H str., Schiff base)

\section{${ }^{1} \mathrm{H} \mathrm{NMR}\left(\mathrm{CDCl}_{3}\right) \delta p p m$}

0.929-0.916,(3H,triplet,- $\left.\mathrm{CH}_{2}-\mathrm{CH}_{3}\right), 1.424-1.528$, (2H,sextet,- $\left.-\mathrm{CH}_{2}-\mathrm{CH}_{3}\right), 1.68-1.804$, (2H,quintet,$\left.\mathrm{CH}_{2}-\mathrm{CH}_{2}-\mathrm{CH}_{3}\right), 2.482$, (3H, singlet, $\left.\mathrm{N}=\mathrm{C}-\mathrm{CH}_{3}\right), 3.985-3.993$, (2H,triplet,- $\left.-\mathrm{OCH}_{2}\right), 6.442-$ $6.458,(2 \mathrm{H}, \mathrm{dd}, \mathrm{Ar}-\mathrm{H}, \mathrm{J}=1.2 \mathrm{~Hz}$.) 7.531-7.911, (6H,complex,Ar $-\mathrm{H}), 11.180,(1 \mathrm{H}$, singlet,$\mathrm{NH}), 13.61,(1 \mathrm{H}$, singlet, $-\mathrm{OH})$

\section{${ }^{13} \mathrm{C} \mathrm{NMR}\left(\mathrm{CDCl}_{3}\right) \delta \mathrm{ppm}$}

161.484(C-1), 14.05(C-2), 167.668 (C-3), 66.809 (C-4), 160.944 (C-5), 106.402(C-6), 129.932 (C-7), 105.124 (C-8), 155.855(C-9), 102.424 (C-10), 67.653(C-11), 31.113(C12), 19.154 (C-13), 14.132(C-14), 128.457(C-15), 112.301 (C-17,19), 121.606 (C-18), 151.925 (C-16,20). Yield: $69 \%$, m.p.: $175^{\circ} \mathrm{C}, \mathrm{R}_{\mathrm{f}}$ Value: 0.37, [Solvent system- Tolune: Ethyl acetate (10 : 1)], Analysis: $\mathrm{C}_{19} \mathrm{H}_{22} \mathrm{~N}_{2} \mathrm{O}_{3}$, Found: C-69.94\%, $\mathrm{H}-6.80 \%, \mathrm{~N}-8.56 \%$ 


\section{1-(4-Butoxy-2-hydroxyphenyl)ethylidene-4-chlorobenzohydrazide (II)}

IR $\left(\mathrm{cm}^{-1}\right)$ : 3310(Ar -OH, Phenol),1182(C-O, Phenol),1265[C-O-C ,(sym)Ether], 1134[C-OC(asym,) Ether], 1670(C=O str. Schiff base),1590(N=C str. Schiff base),3354(N-H str.,Schiff base).

${ }^{1} \mathrm{H} \mathrm{NMR}\left(\mathrm{CDCl}_{3}\right) \delta \mathrm{ppm}$

0.901-0.937,(3H,triplet,- $\left.\mathrm{CH}_{2}-\mathrm{CH}_{3}\right), 1.390-1.444,\left(2 \mathrm{H}\right.$,sextet,- $\left.\mathrm{CH}_{2}-\mathrm{CH}_{3}\right), 1.812-1.829$,(2H,quintet, $\left.-\mathrm{CH}_{2}-\mathrm{CH}_{2}-\mathrm{CH}_{3}\right), 2.426,\left(3 \mathrm{H}\right.$, singlet, $\left.\mathrm{N}=\mathrm{C}-\mathrm{CH}_{3}\right), 3.960-3.990,\left(2 \mathrm{H}\right.$, triplet, $\left.-\mathrm{OCH}_{2}\right), 6.435-6.471$, (2H,dd,Ar-H, J=1.2 Hz.), 7.511-7.533,(1H,doublet, Ar-H) 7.593-7.957, (4H,complex,Ar $\mathrm{H}), 8.142,(1 \mathrm{H}$, singlet, $-\mathrm{NH}), 13.558,(1 \mathrm{H}$, singlet, $-\mathrm{OH})$

${ }^{13} \mathrm{C} \mathrm{NMR}\left(\mathrm{CDCl}_{3}\right) \delta \mathrm{ppm}$

161.441(C-1), 14.15(C-2), 166.781 (C-3), 66.912 (C-4), 161.865 (C-5), 106.454(C-6), 128.971 (C-7), 105.453 (C-8), 155.768(C-9), 102.532 (C-10), 68.124(C-11), 31.091(C12), 19.232 (C-13), 14.438(C-14), 127.897(C-15), 112.342 (C-17,19), 120.789 (C-18), 153.224 (C-16,20). Yield: $67 \%$, m.p.:218 ${ }^{\circ} \mathrm{C}, \mathrm{R}_{\mathrm{f}}$ Value: 0.36, [Solvent system- Tolune: Ethyl acetate (10:1)], Analysis: $\mathrm{C}_{19} \mathrm{H}_{21} \mathrm{ClN}_{2} \mathrm{O}_{3}$, Found: C-63.25\%, H-5.90\%, N-7.73\%, X-9.85\%.

1-(4-Butoxy-2-hydroxyphenyl) ethylidene-4-methylbenzohydrazide (III)

IR $\left(\mathrm{cm}^{-1}\right)$ : 3271 (Ar-OH,Phenol),1180(C-O,Phenol),1270 [C-O-C , (sym)Ether], 1121 [C-O-C (asym,) Ether], 1681(C=O str. Schiff base), 1567 (N=C str. Schiff base), 3242(N-H str.,Schiff base)

${ }^{1} \mathrm{H} \mathrm{NMR}\left(\mathrm{CDCl}_{3}\right) \delta \mathrm{ppm}$

0.901-0.938,(3H,triplet,- $\left.\mathrm{CH}_{2}-\mathrm{CH}_{3}\right), 1.392-1.559,\left(2 \mathrm{H}\right.$, sextet, $\left.-\mathrm{CH}_{2}-\mathrm{CH}_{3}\right), 1.658-1.827,(2 \mathrm{H}$, quintet, $\left.-\mathrm{CH}_{2}-\mathrm{CH}_{2}-\mathrm{CH}_{3}\right), \quad 2.335,\left(3 \mathrm{H}\right.$, singlet, $\left.-\mathrm{CH}_{3}\right), 2.418 \quad\left(3 \mathrm{H}\right.$, singlet, $\left.\mathrm{N}=\mathrm{C}-\mathrm{CH}_{3}\right), 3.957-$ 3.987, (2H, triplet, $\left.-\mathrm{OCH}_{2}\right), 6.432-6.444,(2 \mathrm{H}, \mathrm{dd}, \mathrm{Ar}-\mathrm{H}, \mathrm{J}=1.2 \mathrm{~Hz}),$.6.467 , (1H,doublet, ArH)7.322-7.340,(2H,doublet,Ar -H), 7.823-7.841,(2H,doublet,Ar -H) 8.413, (1H,singlet,$\mathrm{NH}), 13.662,(1 \mathrm{H}$, singlet,-OH)

\section{${ }^{13} \mathrm{C} \mathrm{NMR}\left(\mathrm{CDCl}_{3}\right) \delta p p m$}

161.264(C-1), 14.134(C-2), 164.415 (C-3), 67.687 (C-4), 161.678 (C-5), 106.458(C-6), 128.483 (C-7), 106.458 (C-8), 158.934(C-9), 102.463 (C-10), 68.321(C-11), 31.122(C12), 19.166 (C-13), 14.430(C-14), 129.370(C-15), 113.068 (C-17,19), 128.064 (C-18), 130.651 (C-16,20). Yield: $54 \%$, m.p.: $171^{\circ} \mathrm{C}$, Rf Value: 0.35 , [Solvent system: Tolune: Ethyl acetate (10: 1)], Analysis: $\mathrm{C}_{20} \mathrm{H}_{24} \mathrm{~N}_{2} \mathrm{O}_{3}$, Found: $\mathrm{C}-70.54 \%, \mathrm{H}-7.12 \%, \mathrm{O}-14.10 \%, \mathrm{~N}-8.24 \%$

\section{Results and Discussion}

Spectroscopic analysis

The infrared spectrum has been recorded using the $\mathrm{KBr}$ pellets in the spectral range 4000-400 $\mathrm{cm}^{-1}$. The IR spectra of title compounds I, II and III have been displayed absorption band at 1559,1590 and $1567 \mathrm{~cm}^{-1}$ respectively, which shown characteristics of the $-\mathrm{N}=\mathrm{C}$ str. band.-NH stretching band at $3210 \mathrm{~cm}^{-1}$ is observed and carbonyl group of Schiff base showed characteristic absorption band at $1660 \mathrm{~cm}^{-1}$. The strong broad band observed at $3268 \mathrm{~cm}^{-1}$ recognized the $\mathrm{Ar}-\mathrm{OH}$ and the band due to $\mathrm{C}-\mathrm{O}$ stretching appeared at $1178 \mathrm{~cm}^{-1}$. Due to ether linkage (C-O-C) two bands appeared in the range of 1275-1200 $\mathrm{cm}^{-1}$ (symmetric) and 1019$1020 \mathrm{~cm}^{-1}$ (asymmetric) as stretching band. The aromatic in plane bending was observed at $1117 \mathrm{~cm}^{-1}$. The aromatic out of plane bending was observed at $848 \mathrm{~cm}^{-1}$. Multi substituted benzene ring gives out of plane deformation at $900-860 \mathrm{~cm}^{-1}$ range. At $682 \mathrm{~cm}^{-1}$ band has been observed in compound II which shown that the halogen $(\mathrm{Cl})$ present in the structure.

${ }^{1} \mathrm{H}$ NMR Spectrum of the title compounds (I, II and III) exhibited as singlet of $\mathrm{N}=\mathrm{C}-\mathrm{CH}_{3}$ group at $2.482 \delta \mathrm{ppm}$ and the singlet appeared at $13.61 \delta \mathrm{ppm}$ indicated the presence of $\mathrm{OH}$ group. The proton of $\mathrm{NH}$ shows as singlet at $7.911 \delta \mathrm{ppm}$. In butoxy group, the Sextet 
of $-\mathrm{OCH}_{2}-\mathrm{CH}_{2}-\mathrm{CH}_{2}-\mathrm{CH}_{3-}$ appeared at $1.42-1.52 \delta \mathrm{ppm}$, the triplet of $-\mathrm{CH}_{2}-\mathrm{CH}_{3}$ observed at $0.929-0.916 \delta \mathrm{ppm}$, the quintet of $-\mathrm{OCH}_{2}-\mathrm{CH}_{2}-\mathrm{CH}_{2}-\mathrm{CH}_{3}$ and the triplet of $-\mathrm{OCH}_{2}-\mathrm{CH}_{2}-$ observed at $1.684 \delta \mathrm{ppm}$ and $3.985 \delta \mathrm{ppm}$ respectively. The aromatic region of the spectrum exhibited two protons of the ketonic nucleus as double doublet in the range of 6.442-6.458 $(\mathrm{J}=1.2 \mathrm{~Hz}$. $) \delta \mathrm{ppm}$, while protons of the benzohydrazide nucleus showed as complex pattern integrating five protons in the range of 7.531-7.723 $\delta \mathrm{ppm}$.

In ${ }^{13} \mathrm{C}$ NMR spectra of the title compounds (I, II and III), carbons of the Schiff group were resonated at $161.484 \delta \mathrm{ppm}(\mathrm{C}-1)$ and $14.045 \delta \mathrm{ppm}(\mathrm{C}-2)$. The carbon of carbonyl group $(\mathrm{N}-\mathrm{C}=\mathrm{O})$ resonated at $167.668 \delta \mathrm{ppm}(\mathrm{C}-3)$. The carbons of $-\mathrm{OCH}_{2} \mathrm{CH}_{2} \mathrm{CH}_{2} \mathrm{CH}_{3}$ group showed signals at $14.132 \delta \mathrm{ppm}(\mathrm{C}-14), 19.154 \delta \mathrm{ppm}(\mathrm{C}-13), 31.113 \delta \mathrm{ppm}(\mathrm{C}-12)$, and $67.653 \delta \mathrm{ppm}(\mathrm{C}-11)$. The carbon of $-\mathrm{CO}-\mathrm{CH}_{2}$ group resonated at $66.809 \delta \mathrm{ppm}(\mathrm{C}-4)$. The aromatic carbon showed signals at 102.424 (C-10), 105.124(C-8), 106.402(C-6), 112.301 (C-17), 113.533(C-20), 121.606 (C-19), 128.457 (C-15), 129.932(C-7), 148.118(C18), $155.849(\mathrm{C}-9), 160.944$ (C-5) and $151.925(\mathrm{C}-16, \mathrm{C}-18) \delta \mathrm{ppm}$.

\section{Powder $x$-ray diffraction study}

The crystalline phase of all the compounds are identified at room temperature using Powder $\mathrm{x}$ ray diffraction which routinely has been used as a non-destructive fingerprinting technique in laboratory and industry for several decades. Every solid crystalline compound gives its own unique x-ray diffraction pattern consisting of a set of Bragg peaks. The diffraction pattern for a compound can be considered analogous to a fingerprint, or barcode, with the peak positions determined by the unit cell symmetry and lattice parameters. When we collect XRD data, we can use these fingerprints to identify not only what phases are present in our sample but also index the pattern to obtain information about the unit cell size and shape. The experimental $2 \theta$ range is $2-120^{\circ}$ with a step size of $0.01^{\circ}$ and a counting time of 60 s per step. The program of graphic tool for powder diffraction named Win-PLOTR package ${ }^{16}$ was used to determine the observed diffraction peak positions of the title compound. Analytical indexing of the powder pattern and determination of the space group were performed using EXPO $2009^{17}$, which is designed to launch the most common indexing programs. The powder diffraction patterns for all the title compounds (I, II and III) are presented in the Figure 2. The lattice parameters of the all the compounds are calculated and summarized in Table 1.

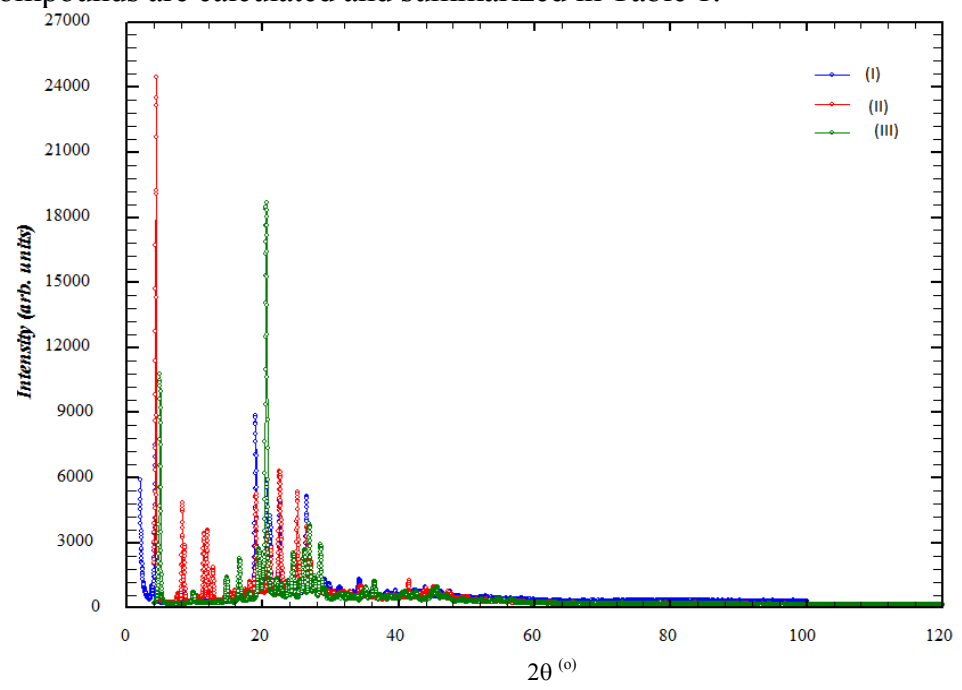

Figure 2. The powder diffraction patterns for the title compounds (I, II and III) 
Table 1. The lattice parameters of the compounds

\begin{tabular}{cccc}
\hline R-group & $4-\mathrm{H}(\mathrm{I})$ & $4-\mathrm{H}(\mathrm{II})$ & $4-\mathrm{H}(\mathrm{III})$ \\
\hline Molecular Weight & $\mathrm{C}_{19} \mathrm{H}_{22} \mathrm{~N}_{2} \mathrm{O}_{3}$ & $\mathrm{C}_{19} \mathrm{H}_{21} \mathrm{~N}_{2} \mathrm{O}_{3} \mathrm{Cl}$ & $\mathrm{C}_{20} \mathrm{H}_{24} \mathrm{~N}_{2} \mathrm{O}_{3}$ \\
\hline \multicolumn{4}{c}{ Lattice Parameters } \\
\hline System & Triclinic & Triclinic & Monoclinic \\
$\mathrm{a}(\AA)$ & 18.2954 & 21.7945 & 29.1853 \\
$\mathrm{~b}(\AA)$ & 5.4862 & 10.9915 & 10.2414 \\
$\mathrm{c}(\AA)$ & 5.1188 & 5.2139 & 22.2292 \\
$\alpha\left({ }^{\circ}\right)$ & 100.1732 & 103.5663 & 90.00 \\
$\beta\left(^{\circ}\right)$ & 92.0484 & 95.9758 & 107.2078 \\
$\gamma\left({ }^{\circ}\right)$ & 97.7921 & 97.1843 & 90.00 \\
Space Group & $\mathrm{P} \overline{1}$ & $\mathrm{P}$ & $\mathrm{P} 2{ }_{1} / \mathrm{n}$ \\
\hline
\end{tabular}

\section{Antimicrobial activities}

Synthesized title compound has been screened for their antimicrobial activity against different panel of organisms, i.e., E.coli, P.aeruginosa, S.aureus, S.pyogenes and antifungal strains C. albicans., using Gentamycin and K. Nystatin as reference standards respectively. The Serial dilution technique was followed by micro method as per NCCLS-1992 manual 21. The observed Minimum Inhibitory Concentrations (MIC) values, for bacterial and fungal strains of the title compound are presented in Table 2. The results revealed that they showed varying degree of inhibition against the tested microorganisms. The MIC values suggest that the tested compound exhibited moderate antibacterial activity against gram negative bacterial strain E.coli and gram positive bacterial strain S. aureus comparable to reference agent Gentamycin.

Table 2. Minimal Inhibition Concentrations of Bacterial Strains (MIC) in $\mu \mathrm{g} / \mathrm{mL}$

\begin{tabular}{|c|c|c|c|c|c|c|c|}
\hline \multirow{2}{*}{$\begin{array}{c}\text { S. } \\
\text { No. }\end{array}$} & \multirow[t]{2}{*}{$-\mathrm{R}$} & \multicolumn{4}{|c|}{$\begin{array}{l}\text { Bacterial activity } \\
\text { Minimal Inhibition Concentrations } \\
\text { (MIC) in } \mu \mathrm{g} / \mathrm{mL}\end{array}$} & \multicolumn{2}{|c|}{$\begin{array}{l}\text { Fungal activity } \\
\text { Minimal Inhibition } \\
\text { Concentration } \\
\text { (MIC) in } \mu \mathrm{g} / \mathrm{mL} \\
\end{array}$} \\
\hline & & $\begin{array}{c}\text { S.aureus } \\
\text { MTCC } \\
96\end{array}$ & $\begin{array}{l}\text { S.pyogenus } \\
\text { MTCC } \\
443\end{array}$ & $\begin{array}{l}\text { E. coli } \\
\text { MTCC } \\
442\end{array}$ & $\begin{array}{c}\text { P.aeruginosa } \\
\text { MTCC } \\
441\end{array}$ & $\begin{array}{c}\text { C.albicans } \\
\text { MTCC } \\
227\end{array}$ & $\begin{array}{c}\text { A.niger } \\
\text { MTCC } \\
282\end{array}$ \\
\hline 1. & $4-\mathrm{H}(\mathrm{I})$ & 250 & 500 & 250 & 500 & 1000 & 200 \\
\hline 2. & 4-Cl (II) & 12.5 & 500 & 12.5 & 500 & 100 & $>1000$ \\
\hline 3. & $4-\mathrm{CH}_{3}$ (III) & 100 & 250 & 100 & 150 & 1000 & 500 \\
\hline Std. & Gentamycin & 0.25 & 0.50 & 0.05 & 1.0 & - & - \\
\hline Drug & K.Nystatin & - & - & - & - & 100 & 100 \\
\hline
\end{tabular}

\section{Conclusion}

A series of novel derivatives, 1-(4-butoxy-2-hydroxyphenyl) ethylidene- benzohydrazide (I), 1-(4-butoxy-2-hydroxy phenyl) ethylidene-4-chloro benzohydrazide (II) and 1-(4-butoxy-2hydroxy phenyl) ethylidene-4-methyl benzohydrazide (III) have been synthesized by Schiff base method. The spectroscopic characterizations have been confirmed by the chemical analysis, IR, 1H NMR and 13C NMR. Powder X-ray diffraction graph shows that the synthesized compounds have been crystalline in nature and it belongs to triclinic and monoclinic systems. From the results of biological study, it is clear that the chlorine containing schiff base derivative exhibit more degree of inhibition against specific bacteria. 


\section{Acknowledgements}

Dr. V. M. Barot is also thankful to the management and the principal of Smt. S. M. Panchal Science College, Talod, who provided all kinds of facilities during the research work.

\section{References}

1. Szliszka E, Czuba Z P, Mazur B, Sedek L, Paradysz A and Krol W, Int J Mole Sci., 2010, 11(1), 1-13; DOI:10.3390/ijms 11010001

2. Awasthi S K, Mishra N, Kumar B, Sharma M, Bhattacharya A, Mishra L C and Bhasin V K, Medicinal Chem Res., 2009, 18(6), 407-420; DOI:10.1007/s00044-008-9137-9

3. Okunrobo L O, Usifoh C O and Uwaya J O, Acta Poloniae Pharmaceutica - Drug Research, 2006, 63, 195-199.

4. Wu Jiu H, Wang Xi H, Yi, Yang H and Lee Kuo H, Bioorg Med Chem Lett., 2003, 13(10), 1813-1815; DOI:10.1016/S0960-894X(03)00197-5

5. Tan N D and Dao T T, Pharmacology Pharmacy, 2011, 2(4), 282-288; DOI:10.4236/pp.2011.24036

6. Sivakumar P M, Cometa S, Alderighi M, Veluchamy P, Doble M and Federica C, Carbohydrate Polymers, 2012, 87(1), 353-360; DOI:10.1016/j.carbpol.2011.07.061

7. Hasan A, Rasheed L and Malik A, Asian J Chem., 2007, 19(2), 937-948.

8. Zandi K, Teoh, Boon-T, Sam Sing-S, Wong Pooi-F, Mustafa M R and AbuBakar S, $J$ Med Plants Res., 2011, 5(23), 5534-5539.

9. Kaushik S, Kumar N and Drabu S, Pharma Research, 2010, 3(1), 257-262.

10. Satyanarayana, M, Tiwari P, Tripathi B K, Srivastava A K and Pratap R, Bioorg Med Chem., 2004, 12(5), 883-889; DOI:10.1016/j.bmc.2003.12.026

11. Patel U H and Gandhi S A, Indian J Pure Appl Phys., 2008, 49, 263-269.

12. Patel U H, S A Gandhi, Barot V M and Patel M C, Acta Cryst., 2009, E68(10), o2926-2927; DOI:10.1107/S1600536812038275

13. Patel U H, Gandhi S A, Barot V M and Patel M C, Crystal Structure Theory Applications, 2013, 2, 167-175.

14. Dhar D N and Taploo C L, J Sci Ind Res., 1982, 41, 501-506.

15. Arulmurugan S, Kavitha P H and Venkatraman R P, Rasayan J Chem., 2010, 3(3), 385-410.

16. Roisnel T and Rodriguez-Carvajal J, Analysis Mater Sci Forum, 2001, 378(1), 118-123.

17. Altomare A, Cuocci C, Giacovazzo C, Moliterni A, Rizzi R, Corriero N and Falcicchio A, J Appl Cryst., 2013, 46(4), 1231-1235; DOI:10.1107/S00218898-13013113

18. National Committee for Clinical Laboratory Standard. Reference method forxbroth dilution antifungal susceptibility testing of yeasts Approved standard M27A (1997), NCCLS, Wayne, PA.

19. Anne Monks, Dominik Scudiero, Skehan P, Schoemaker R, Paull K, Vistica D, Hose C, Langley J, Cronise P, Vaigro-Wolff A, Gray-Goodrich M, Campbell H, Mayo J and Boyd M, J Natl Cancer Inst., 1991, 83, 757. 